\title{
Use of Monitoring Approaches to Verify the Predictive Accuracy of the Modeling of Particle-Bound Solid Inputs to Surface Waters
}

\author{
Katharina Allion ${ }^{1, *(\mathbb{D})}$, Michael Gebel ${ }^{2}$, Mario Uhlig ${ }^{2}$, Stefan Halbfass ${ }^{2}$, Stephan Bürger ${ }^{2}$, Lisa Kiemle ${ }^{1}$ (D) \\ and Stephan Fuchs ${ }^{1}$ (D)
}

1 Department of Aquatic Environmental Engineering, Institute for Water and River Basin Management, Karlsruhe Institute of Technology (KIT), Gotthard-Franz-Str. 3, 76131 Karlsruhe, Germany; lisa.kiemle@kit.edu (L.K.); stephan.fuchs@kit.edu (S.F.)

2 VisDat Geodatentechnologie GmbH, Am Ende 14, 01277 Dresden, Germany; micha.gebel@visdat.de (M.G.); mario.uhlig@visdat.de (M.U.); stefan.halbfass@visdat.de (S.H.); stephan.buerger@visdat.de (S.B.)

* Correspondence: katharina.allion@kit.edu

Citation: Allion, K.; Gebel, M.; Uhlig, M.; Halbfass, S.; Bürger, S.;

Kiemle, L.; Fuchs, S. Use of

Monitoring Approaches to Verify the Predictive Accuracy of the Modeling of Particle-Bound Solid Inputs to Surface Waters. Water 2021, 13, 3649. https://doi.org/10.3390/w13243649

Academic Editor: Aizhong Ye

Received: 16 November 2021

Accepted: 17 December 2021

Published: 18 December 2021

Publisher's Note: MDPI stays neutral with regard to jurisdictional claims in published maps and institutional affiliations.

Copyright: (c) 2021 by the authors. Licensee MDPI, Basel, Switzerland. This article is an open access article distributed under the terms and conditions of the Creative Commons Attribution (CC BY) license (https:// creativecommons.org/licenses/by/ $4.0 /)$.

\begin{abstract}
For particle-bound substances such as phosphorus, erosion is an important input pathway to surface waters. Therefore, knowledge of soil erosion by water and sediment inputs to water bodies at high spatial resolution is essential to derive mitigation measures at the regional scale. Models are used to calculate soil erosion and associated sediment inputs to estimate the resulting loads. However, validation of these models is often not sufficiently possible. In this study, sediment input was modeled on a $10 \times 10 \mathrm{~m}$ grid for a subcatchment of the Kraichbach river in Baden-Wuerttemberg (Germany). In parallel, large-volume samplers (LVS) were operated at the catchment outlet, which allowed a plausibility check of the modeled sediment inputs. The LVS produced long-term composite samples ( 2 to 4 weeks) over a period of 4 years. The comparison shows a very good agreement between the modeled and measured sediment loads. In addition, the monitoring concept of the LVS offers the possibility to identify the sources of the sediment inputs to the water body. In the case of the Kraichbach river, it was found that around $67 \%$ of the annual sediment load in the water body is contributed by rainfall events and up to $33 \%$ represents dry-weather load. This study shows that the modeling approaches for calculating the sediment input provide good results for the test area Kraichbach and the transfer for a German wide modeling will produce plausible values.
\end{abstract}

Keywords: sediment input; erosion; suspended solids; composite samples; large-volume sampler; rating curve

\section{Introduction}

Particle-bound substance inputs to surface waters still contribute significantly to missed legal quality standards [1,2] by many water bodies [3,4]. A relevant source for solid inputs is erosion by water. Especially substances transported attached to solids such as phosphorus $(\mathrm{P})$ or heavy metals; erosion is an important input pathway to surface water $[5,6]$. In order to derive effective measures for emission reduction, knowledge of the sources and input pathways of substances is essential. The need to quantify substance inputs to surface waters and derive adapted mitigation strategies stimulated the development of diverse model systems at the regional scale [7-18]. These models have in common that they used predominantly empirical or stochastic rather than process-related approaches. The validation of the model results is usually done by the comparison of calculated emissions with river loads derived from flow and quality measurements. The basis are usually randomly distributed concentration measurements in combination with discharge at gauging stations as part of routine sampling by the water authorities. Eventrelated measurements or measurements representative of certain flow conditions, e.g., during dry weather periods, are not systematically taken into account. As a result, the 
calculated river loads may differ significantly from continuous sampling, which is very time-consuming and expensive and thus hardly available [19-21]. Long-term composite samples instead of grab samples are better suited here, as they capture the load in the water body more realistically [19-21].

Europe-wide model results for soil erosion by water are available from Panagos et al. [22], and sediment input using the newest data available for this scale from Borrelli et al. [16]. Panagos et al. [22] highlight the possibility that proper mitigation measures and scenarios can be derived with these data. For Germany, modeling results of soil erosion by water based on the universal soil-loss equation (USLE, [23]) is available from Wurbs and Steininger [24] and the Federal Institute for Geosciences and Natural Resources [25], among others. Individual factors of the USLE were recently adapted by Plambeck [26] and Auerswald et al. $[27,28]$ and were also calculated nationwide.

Long-term studies on soil erosion monitoring exist, for example, for Switzerland; otherwise, recent studies considering current professional management practices are rare [29]. Poesen [30] points out that measurements for soil erosion are often performed only on a single slope whereas sediment input is calculated for larger hydrological units. This also emphasizes that long-term monitoring on catchment scale is strongly needed to support model validation.

The calculation of sediment input on a $10 \times 10 \mathrm{~m}$ grid and the associated particulate $\mathrm{P}$ input in German river systems is the subject of a project initiated by the Federal Environment Agency [31] and the results are used in this study. For the modeling, algorithms that have already been tested and validated in various research projects and in different regions are used (Germany, China, South Africa) [11,12,32].

In a hotspot area of soil erosion by water and sediment input (Kraichbach river) LVS (large-volume sampler) were installed and operated continuously over a period of several years $[33,34]$.

The large-volume sampler method was introduced in Fuchs et al. [35] and Kemper et al. [36] and has been used in several studies examining combined sewer overflows [37-39]. The different sampling strategies realized with LVS are described in detail in Nickel and Fuchs [38]. LVS can also be used to monitor quality of surface waters and thus validate model results on substance emissions [6,40].

In the Kraichbach catchment, the modeled sediment inputs are validated against measured solids loads from the LVS in the river. The measured loads were additionally used to separate the particle-bound emission pathways from the dissolved emission pathways, which helps to facilitate a source-related evaluation (agriculture, sewer systems) and improves the quality of the validation.

In this respect, the work in the Kraichbach area is a way to exemplarily verify the approaches used to calculate long-term mean sediment inputs from soil erosion by water. Based on this, the model procedure will be used to represent the sediment inputs in the Federal Republic of Germany. In order to avoid scale-related biases, the modeling will be carried out both in the Kraichbach area and nationwide on a $10 \mathrm{~m}$ raster and with the same data basis.

This paper presents the monitoring and modeling work in the Kraichbach area and compares the results.

\section{Materials and Methods}

\subsection{The Study Area: Kraichbach}

The study area is a sub-catchment of the Kraichbach river. The Kraichbach is located in the north-west of Baden-Wuerttemberg (Germany) and has a flow length of about $55 \mathrm{~km}$. The upper reaches of the Kraichbach are located in the Kraichgau, an intensively farmed area with fertile loess soils and a relatively dense population. After about half of its length, the Kraichbach flows through the upper Rhine valley and enters the Rhine river at the village of Ketsch. The gauging station 'Ubstadt' is located at this transition zone between the Kraichgau and the upper Rhine valley and covers an area of $160 \mathrm{~km}^{2}$. 
The Kraichbach was chosen as study area because the catchment area is strongly influenced by agriculture. Approximately $50 \%$ of the area is used for agriculture (Figure 1). The loess soils of the Kraichgau and its hilly topography also contribute to the fact that the soils are prone to erosion.

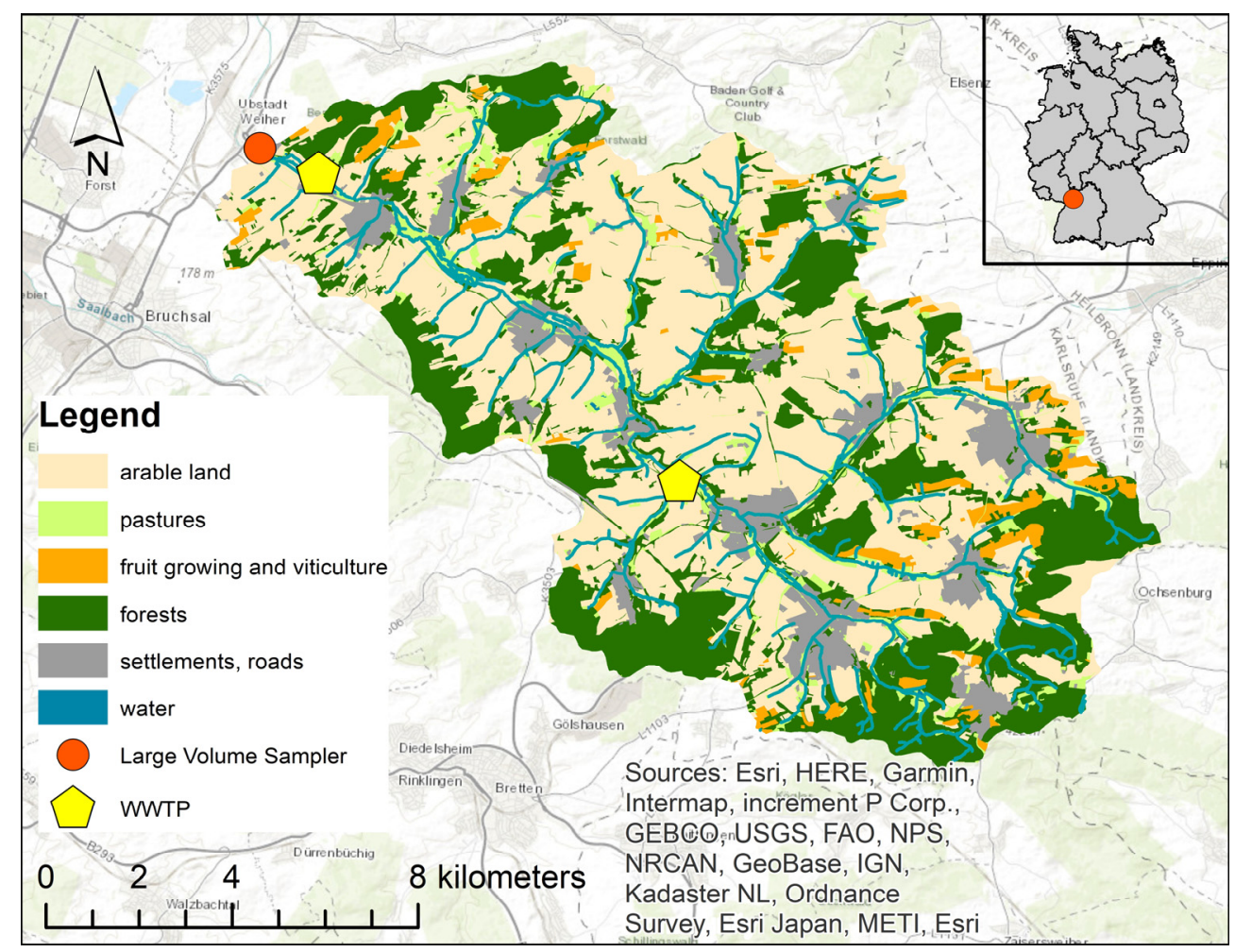

Figure 1. Land use in the Kraichbach study area.

Urban factors also influence the water quality of the upper Kraichbach catchment. Two wastewater treatment plants are located upstream of the gauging station 'Ubstadt' (Figure 1). According to Wagner [33], for the years 2009-2014, the wastewater treatment plants have a mean wastewater flow of 2.5 and 3.3 million $\mathrm{m}^{3}$ per year, respectively, which corresponds to about $15 \%$ of the river discharge at the gauging station. The annual precipitation in the study area is about $700 \mathrm{~mm} \mathrm{a}^{-1}$ [33].

\subsection{Monitoring with the Large-Volume Sampler \\ 2.2.1. Monitoring Campaign}

Large-volume samplers increasingly used for the monitoring of sewer systems and surface waters [38]. A LVS has also been in use on the Kraichbach river since 2017 to investigate the transport of sediment in the water body. In contrast to the event sampling in sewer systems described by Nickel and Fuchs [38], the sampling at the Kraichbach operated as a continuous long-term sampler. The LVS are in operation throughout the year, except in the case of technical defects, during the collection of samples from the LVS, or during periods of freezing temperatures.

The mean annual flow rate (MQ) of the gauging station at the Kraichbach is $1.1 \mathrm{~m}^{3} \mathrm{~s}^{-1}$. The LVS was used to sample a wide range of flow situations over the four-year period.

\subsubsection{Large-Volume Sampler}

The large-volume sampler consists of a $1000 \mathrm{~L}$ stainless steel tank. Over two to four weeks, discharge-proportional long-term composite samples are collected in the tank. The pump is controlled by the water level signal from the neighboring gauging station 'Ubstadt' to take a $10 \mathrm{~L}$ subsample from the river after a certain discharge volume and collect it in 
the tank. A float switch prevents the tank from overflowing. The schematic of the LVS is shown in Figure 2.

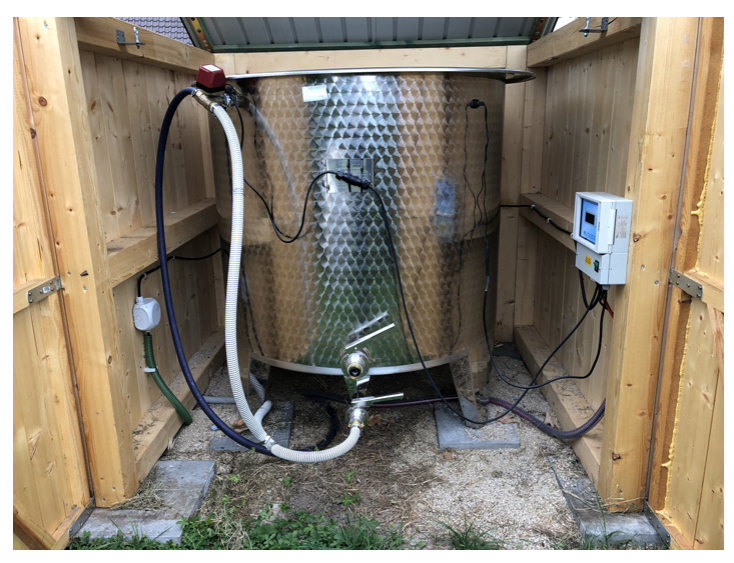

(a)

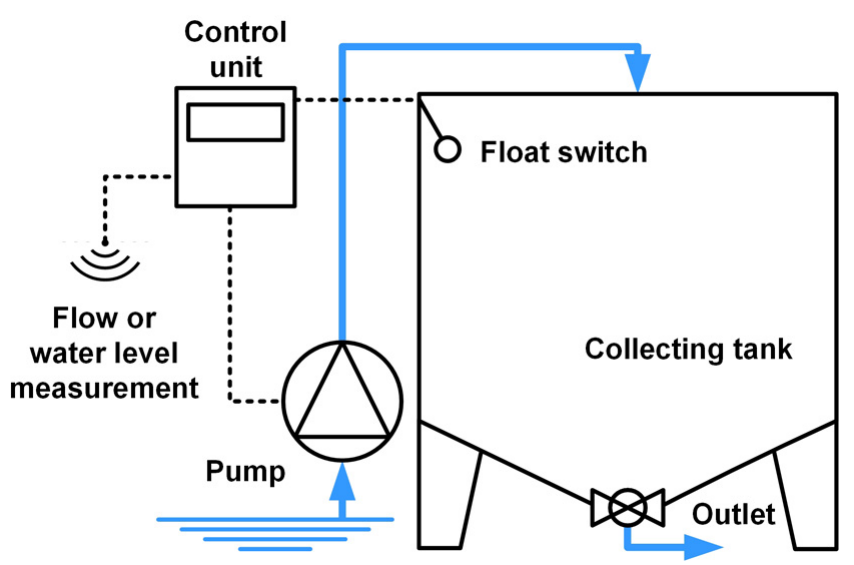

(b)

Figure 2. Schematic of the large-volume sampler: (a) photo of the large-volume sampler; (b) sketch of the large-volume sampler [38].

After a settling period of three to four days, the solid sample and the supernatant water are collected and analyzed separately. From the supernatant water a 2 L sample is taken to quantify the completeness of the sedimentation and the concentration the dissolved substances. The settled solids provide information on the particulate-transported substances. The solid samples are collected in $15 \mathrm{~L}$ stainless steel cans, after the supernatant water is drained to the river using faucets.

Mineralization of the organic solids may occur under certain conditions during the settling time resulting in a reduction of the total mass of sediment. This aspect was not investigated in detail in this study. However, considering the organic content (loss on ignition) after the sedimentation process, which accounts to $12 \%$ for the fine fraction $(<63 \mu \mathrm{m})$ and $35 \%$ for the sand fraction, the loss of mass is assumed negligible.

An overview of the LVS settings on the Kraichbach river is summarized in Table 1. Further information can be found in Allion et al. [34].

Table 1. Properties of the large-volume sampler at the Kraichbach river.

\begin{tabular}{cc}
\hline Property & Large-Volume Sampler \\
\hline Sampling period & March 2017-June 2021 \\
Number of sampling periods & 43 \\
Sampling strategy & Volume-proportional, long-term \\
Sampling interval & $13,300 \mathrm{~m}^{3}$ \\
Subsample volume & $10-15 \mathrm{~L}$ \\
Tank volume & Stainless steel, $1000 \mathrm{~L}$ \\
Samples per container & 100 \\
Pumping system & Peristaltic \\
Pump capacity & $15,000{\mathrm{~L} \cdot \mathrm{h}^{-1}}$ \\
\hline
\end{tabular}

\subsubsection{River Mean Concentrations}

The samples were used to calculate river mean concentrations of suspended solids for the sampled period (sampling period mean concentrations (SPMC)). The sampled discharge volume is comparable in all sampling periods, because the tank is always filled to at least $80 \%$ capacity. This means that each calculated SPMC represents a discharge volume of around 0.9 million $\mathrm{m}^{3}$. The SPMC is calculated for the parameter dry mass of the sediment and the remaining solid concentration in the supernatant water and represents therefore the complete amount of solids transported in the river [34]. The relationship 
between the SPMC and the maximum discharge during the sampling periods can be expressed by a rating curve.

\subsubsection{Annual River Loads}

Based on the rating curve and hourly available discharge data of the gauging station, annual suspended solid loads were calculated by Allion et al. [34]. For this purpose, the discharge data were divided into volume segments of 0.9 million $\mathrm{m}^{3}$, representing the sampling periods. Since the rating curve represents the relationship between the maximum discharge during sampling and the resulting concentrations, each volume segment was assigned an average concentration from the rating curve based on the maximum discharge. The approach is described in detail by Allion et al. [34].

\subsubsection{Dry-Weather Load}

Suspended solids collected in the LVS, result from different sources. The dry-weather load, for example, represents the inputs via wastewater treatment plant effluents, groundwater and internal loading. While wet-weather flows comprise additional inputs from agricultural areas (erosion) and urban areas (combined sewer overflow) because of significant rain events. Since the modeling of sediment input only captures the component resulting from erosion, a dry-weather load in the Kraichbach has to be defined and determined to separate the erosion-related emissions from the other sources.

Fuchs et al. [41] define the dry-weather load as discharges $\leq 2.5 \mathrm{~m}^{3} \mathrm{~s}^{-1}$ (approx. $2 \mathrm{MQ}$ ) for the river Kraichbach. They stated that up to this discharge no systematic relation between discharge and solid concentration could be found. However, the authors point out that this dry-weather load also includes rainfall events. Therefore, the threshold for the dry-weather load was adapted and set to the limit of $1.65 \mathrm{~m}^{3} \mathrm{~s}^{-1}$ (1.5MQ) considering the measured values. Rainfall events cannot be completely excluded here neither. However, based on the given data it seems to be more likely that the concentrations are not systematically influenced by runoff processes. Because of the given uncertainties not only the median concentration but also the range of the 25th and 75th percentiles is considered.

To derive the concentrations for calculating the dry-weather load, the samples with maximum discharge $\leq 1.65 \mathrm{~m}^{3} \mathrm{~s}^{-1}$ are extracted from the LVS data set.

\subsection{Modeling Approaches of the Sediment Input}

For the estimation of soil erosion by water, the USLE (universal soil-loss equation) developed by Wischmeier and Smith [23] and the ABAG (general soil-erosion equation) derived from it by Schwertmann et al. [42] for central European conditions are often used. In the standard DIN 19708 (2017), the procedure for determining soil erosion according to ABAG for agriculturally used arable soils is detailed on the basis of input data that are predominantly digital and available for large areas. In contrast to more process-based erosion models, such as Erosion 3D $[43,44]$ or the temporally higher-resolution USLEM [45], ABAG does not represent soil erosion due to individual events, but rather the long-term expected average areal soil erosion, due to rainfall [23]. Soil erosion due to snowmelt, on the other hand, is not considered. It should further be noted that the ABAG approach only considers sheet, rill and interrill erosion (DIN 19708 2017). The linear erosion forms of channel or gully erosion remain unrecognized in the quantification at the catchment level and are consequently not accounted for [46]. The long-term mean soil erosion by water $\mathrm{A}\left[\mathrm{t} \mathrm{ha}{ }^{-1} \mathrm{a}^{-1}\right]$ results as follows (Equation (1)):

$$
\mathrm{A}=\mathrm{R} \times \mathrm{K} \times \mathrm{C} \times \mathrm{L} \times \mathrm{S} \times \mathrm{P},
$$

with $\mathrm{A}$ as long-term mean soil erosion in $\mathrm{tha} \mathrm{h}^{-1} \mathrm{a}^{-1}, \mathrm{R}$ as surface runoff and rainfall erosivity factor $[\mathrm{N} /(\mathrm{h} \cdot \mathrm{a})], \mathrm{K}$ as soil erodibility factor $[(\mathrm{Mg} \cdot \mathrm{h}) /(\mathrm{ha} \cdot \mathrm{N})], \mathrm{L}$ as slope length factor (dimensionless), $\mathrm{S}$ as slope inclination factor, $\mathrm{C}$ as cover and tillage factor and $\mathrm{P}$ as factor to account for erosion control measures. 
For the R-factor, the calculations by Auerswald et al. [27] and Fischer et al. [47] are used for the period of 2001 to 2017 in a $1 \mathrm{~km}^{2}$ grid based on temporally high-resolution radar-based precipitation data, using the original equation of Wischmeier and Smith [23]:

$$
\mathrm{R}_{\mathrm{e}}=\mathrm{I}_{\max 30} \times \mathrm{E}_{\mathrm{kin}}
$$

with $R_{e}$ as the erosivity of a single rain event $\left[\mathrm{N} \mathrm{h}^{-1}\right], I_{\max 30}$ as the maximum 30 min rain intensity $\left[\mathrm{mm} \mathrm{h}^{-1}\right]$ and $\mathrm{E}_{\mathrm{kin}}$ as the total kinetic energy per unit area $\left[\mathrm{KJ} \mathrm{m}^{-2}\right]$.

The R-factors derived from this data basis are about $50 \%$ higher than the values resulting from DIN 19708 (2017), which can be attributed on the one hand to the influence of climate change, but on the other hand also to the stronger consideration or lower smoothing of events compared to the regression-analytical derivation of R-factors according to Sauerborn [48] proposed in DIN 19708 (2017) [27].

The K-factor is determined for the topsoil horizon on the basis of DIN 19708 (2017) [27], which fully implements the requirements of Schwertmann et al. [42], whereby simplifications are necessary due to missing data in the BUEK 200 (soil overview map 1: 200,000, [49]). The calculation is performed in three stages, adapted to the soil nomenclature applicable in Germany, taking into account the fine soil mass fractions of silt, clay and sand, the humus content (based on the humus stage) and the permeability class (from water conductivity per soil type subgroup and storage density or dry bulk density). The respective equations for the three stages are automatically controlled via a decision tree in the soil database.

Deviating from the model conception of the USLE [23], which fully implements the requirements of the L- and S-factors (according to RUSLE, see [50]) are derived in a twodimensional approach with a multiple flow algorithm according to Moore and Nieber [51] using the GIS modules in open-source software SAGA-GIS as a summarized LS-factor on the $10 \mathrm{~m}$ grid for each grid cell and the overlying specific catchment area (SCA):

$$
\left.\mathrm{LS}=1.4 \times(\mathrm{SCA} / 22,13)^{0.4} \times(\sin \beta / 0.0896)^{1.3}\right)
$$

with SCA as specific catchment area $\left[\mathrm{m}^{2}\right], B$ as the slope $\left[{ }^{\circ}\right]$.

For the derivation in SAGA-GIS the methods "field-based" / "Moore and Nieber" / "distance-weighted average catchment area" / "contour length simply as cell size" were chosen, resulting in the highest LS values in comparison. Furthermore, barriers in the landscape are considered, which limit the respective delivery areas (unit contributing areas UCA, [50]). Calculations are performed field by field, which means that catchment area calculation is restricted to each field's area. Studies of selected experimental plots by Hrabalíková and Janeček [52] show that this approach yields slightly lower values compared to the original one-dimensional approach by Wischmeier and Smith [23] considering the erosion-effective slope length. However, the agreements compared to the original approach are higher on these plots than when using the method of Desmet and Govers [53], which is also available in SAGA-GIS. Comparing with already available literature results [22,26] based on the Desmet and Govers [53] procedure, though, there are no major deviations from the results obtained here. The catchments derived for each grid cell are limited by the parcel boundaries extracted from the ATKIS-DLM. Thus, the magnitude of the LS factors depends not only on the algorithm used, the raster resolution, and the resolution of the elevation model used, but especially on the parcel size. It is assumed here that parcels are bounded by paths that limit the delivery areas.

C-factors were calculated for the districts of the Federal Republic of Germany (crop type distribution 2016-2018) for the arable land within the framework of an ongoing UBA project (FKZ 3719432033) with the proportional inclusion of tillage (plow, mulch sowing/direct sowing per federal state or administrative district) (see [54,55]). Methodologically, the calculation of C-factors [23,42] for arable land follows the method documented in Wurbs and Steininger [24] taking into account the crop rotations used there. C-factors for noncropland are disaggregated for the respective uses according to Panagos et al. [56] (data source: European Soil Data Centre (ESDAC), data status 2010, resolution $100 \mathrm{~m}$ ). 
The P-factor is set to ' 1 ', since no usable information on the lateral treatment of the slope is available.

When evaluating the model results for soil erosion by water, it should generally be noted that the selected grid size in the model has a significant influence on the modeling. There is a tendency for soil erosion to level off as the grid size increases because the spatial variability of the original relief parameters decreases as a result of aggregation [57]. For this reason, a grid size of $10 \mathrm{~m}$ was chosen in the present project, which is as high a resolution as possible for the calculation planned nationwide, but which can still provide sufficiently good results in the study area of the Kraichbach.

The method for modeling sediment inputs to water systems developed for the medium-scale range [11,12,32,58-62] determines, on the basis of generally available data as well as modeled soil erosion by water, for each grid cell:

- Area connection to the watercourse system;

- Watercourse distance;

- Connectivity probability;

- Sediment delivery ratio;

- Grid-related sediment input.

It can be assumed that only a small proportion of the eroded soil material is introduced into surface waters. At the same time, the input of sediment and particulate matter is limited to those areas with a short distance to the watercourse or a high degree of connection to the surface water [58,63]. This is caused, among other things, by the transport power of surface water runoff as well as deposition and accumulation of eroded soil in the terrain.

The area connectivity describes the hydrological connectivity of an area (grid cell) with the water body accessible via surface runoff on the natural flow path. Linear (roads, paved paths, railroads, etc. from ATKIS-DLM) and areal landscape elements (e.g., settlement area) are classified as barriers that cap the flow path. A GIS and model-based separation process is used to determine the hydrologically connected areas or the areas that are considered non-entry-relevant based on the defined barriers. Areas that are not relevant to discharge are not taken into account when determining sediment input to surface waters.

Input data for calculation of the surface connectivity are a digital terrain model (DTM 10, [64]) and a land-use dataset (ATKIS-DLM, [65]).

The GIS technical routines for tracking the depth lines to map the watercourse distance are performed with the program package SAGA GIS using a multiple flow approach [66-69]. Grid cells for which a watercourse distance cannot be calculated because the flow path to a watercourse is not realized are considered unconnected. The watercourse distance $1_{\text {flow }}$ is derived from the flowpath lengths calculated as part of the hydrologic connectivity determination, measured from the respective grid cell to the point where it reaches the watercourse network under consideration of the DTM 10.

In the present empirical modeling approach, sediment inputs to water bodies due to soil erosion by water are abstracted and estimated using the sediment-delivery ratio (SDR). The SDR describes the ratio between soil erosion (gross erosion) from the surface and sediment input to surface waters. Thus, it is a measure of the efficiency of sediment transport from the eroding surface to the receiving water. According to Halbfass and Grunewald [62], SDR is determined via the relationship.

$$
\operatorname{SDR}=x_{i}\left(s / 1_{\text {flow }}\right)^{(1-P)}
$$

with $x_{i}$ as the utilization coefficient, $\mathrm{s}$ as the slope $\left[\mathrm{m} \mathrm{m}^{-1}\right], 1_{\text {flow }}$ as the mean watercourse distance $[\mathrm{m}]$, and $\mathrm{P}$ as the connectivity probability. The coefficient of utilization $\mathrm{x}_{\mathrm{i}}$ is derived from the $\mathrm{C}$-factor according to the following equation:

$$
x_{i}=1.43 \ln (C \text {-factor })+9.49
$$


The connectivity probability $\mathrm{P}$ is calculated from the conditional probabilities for the watercourse distance $P_{\text {lflow }}$, the soil erosion $P_{A}$, and the surface runoff $P_{R O}$ (see [58,60-62]:

$$
\mathrm{P}=\sqrt{ }\left(\mathrm{P}_{\text {lflow }}{ }^{2}+\mathrm{P}_{\mathrm{A}}^{2}+\mathrm{P}_{\mathrm{RO}}{ }^{2}\right)(0 \leq \mathrm{P} \leq 1)
$$

with the following equations for $\mathrm{P}_{\text {lflow }}, \mathrm{P}_{\mathrm{A}}$ and $\mathrm{P}_{\mathrm{RO}}$ :

$$
\begin{aligned}
\mathrm{P}_{\text {Iflow }} & =-0.1358 \ln \left(\mathrm{l}_{\text {flow }}\right)+0.97107, \mathrm{R}^{2}=0.94\left(0<\mathrm{l}_{\text {flow }} \leq 1000 \mathrm{~m}\right) \\
\mathrm{P}_{\mathrm{A}} & =0.0671 \ln (\mathrm{A})+0.1557, \mathrm{R}^{2}=0.85\left(\mathrm{~A} \geq 0.1 \mathrm{tha}^{-1} \mathrm{a}^{-1}\right) \\
\mathrm{P}_{\mathrm{RO}} & =0.0386 \ln (\mathrm{RO})+0.0994, \mathrm{R}^{2}=0.96\left(\mathrm{RO} \geq 0.1 \mathrm{~mm} \mathrm{a}^{-1}\right)
\end{aligned}
$$

Regarding surface runoff (RO), the direct runoff component calculated in the substance emissions model system MoRE (modeling of regionalized emissions) is used as the average value of the years 2001 to 2016 [10].

In conclusion, the sediment input SE to surface waters of agricultural land from hydrologically connected land results from:

$$
\mathrm{SE}=\mathrm{SDR} \times \mathrm{A}
$$

with SE $\left[\mathrm{t} \mathrm{a}^{-1}\right]$ as use-specific sediment input, and $\mathrm{A}\left[\mathrm{t} \mathrm{ha}^{-1} \mathrm{a}^{-1}\right]$ as soil erosion by water.

\section{Results}

\subsection{River Concentrations}

A total of 43 composite samples were collected from March 2017 to June 2021, from which mean substance concentrations can be derived. The highest flow peak captured during a sampling period was $6.7 \mathrm{~m}^{3} \mathrm{~s}^{-1}$ (6MQ). The resulting rating curve is shown in Figure 3. It describes the dependence of the suspended solid concentration and the maximum discharge $Q_{\max }$ of the sampling period. All composite samples taken represent a mean discharge volume of the Kraichbach river of 0.9 million $\mathrm{m}^{3}$. The threshold for the dry weather flow is marked with a line at $1.65 \mathrm{~m}^{3} \mathrm{~s}^{-1}$.

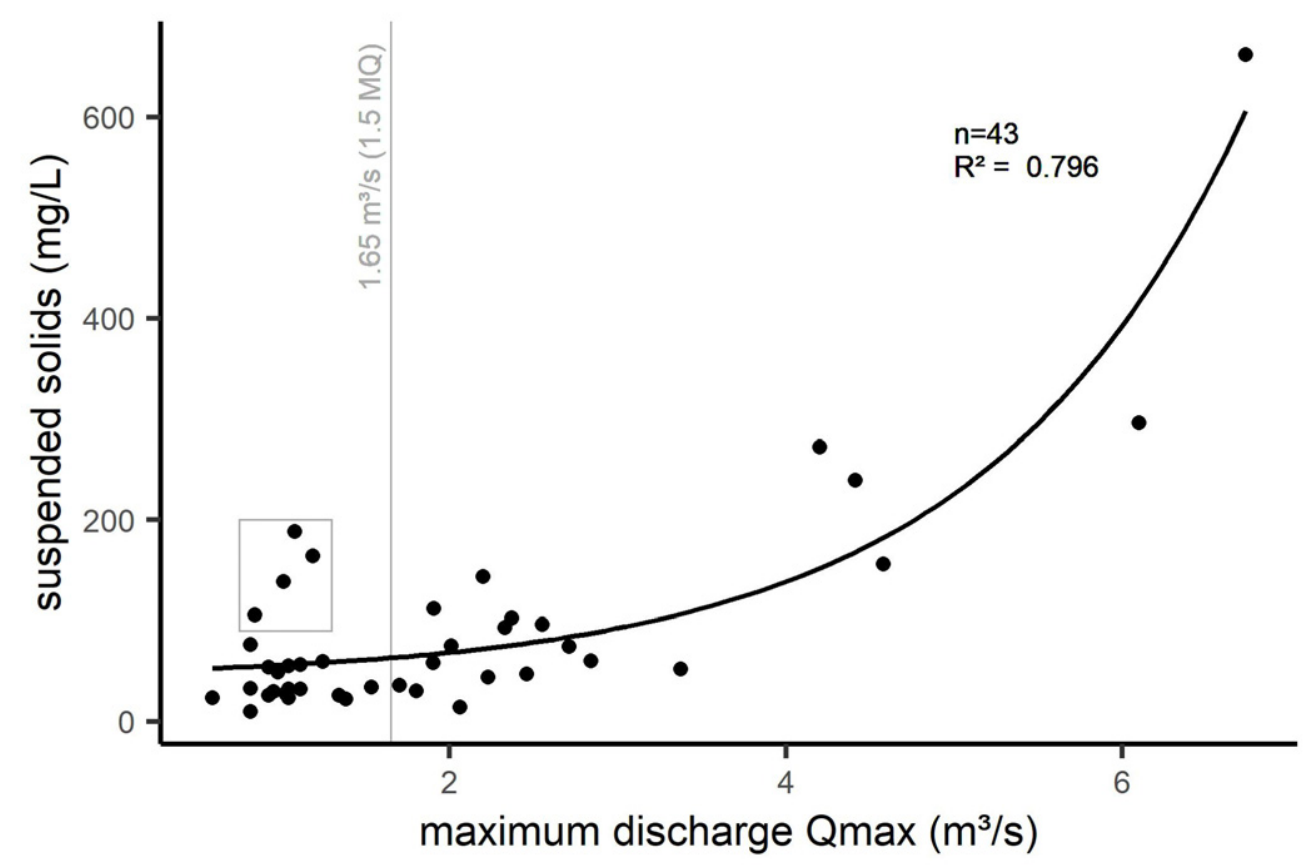

Figure 3. Rating curve of the Kraichbach with the threshold of $1.65 \mathrm{~m}^{3} \mathrm{~s}^{-1}$ for the dry weather flow. Outliers are marked with a box. 


\subsubsection{Concentrations during Dry Weather Flow}

To determine a median concentration during the dry weather conditions, the samples in the range $\leq 1.65 \mathrm{~m}^{3} \mathrm{~s}^{-1}$ are used (Figure 3). It is noticeable that there are four very high concentrations at discharge around MQ (up to $200 \mathrm{mg} \mathrm{L}^{-1}$, marked with a box). These are situations where the solid transport and discharge are obviously completely decoupled. These solid concentrations are excluded from further analysis because they do not represent a specific flow situation but are caused by random disturbances.

The median, 25th and 75th percentile dry weather concentrations are calculated without the outliers. The results are shown in Table 2. The determined concentrations of dry weather situations are in the range of about 26 to $51 \mathrm{mg} \mathrm{L}^{-1}$.

Table 2. Concentrations during dry weather in the Kraichbach river.

\begin{tabular}{cc}
\hline Parameter & Suspended Solid Concentration in $\mathbf{~ m g ~ L ~}^{-\mathbf{1}}$ \\
\hline 25th percentile & 25.8 \\
Median & 31.9 \\
75th percentile & 51.1 \\
\hline
\end{tabular}

\subsubsection{Concentrations during Erosion Events}

With increasing discharge, the amount of transported solids in the water rise (Figure 3). In the range of 4 to $6 \mathrm{MQ}$, the concentrations are about $220 \mathrm{mg} \mathrm{L}^{-1}$. At discharges in the range of $6 \mathrm{MQ}$, up to $660 \mathrm{mg} \mathrm{L}^{-1}$ are reached. These high concentrations in the Kraichbach river are influence by erosion processes.

\subsection{Determined Sediment Loads for Long-Term Discharges Based on Monitoring}

The applications of the rating curve for a long period of discharged monitoring result in annual suspended solid loads, summarized in Figure 4. The annual fluctuations of the loads calculated clearly show the influence of flood events and erosion. In years with serious floods like 2003 and 2013, more than $5000 \mathrm{t}$ per year of suspended solids are emitted into the Kraichbach. For the whole observation period of 2003-2020, the mean load is approximately $2800 \mathrm{t}$ per year.

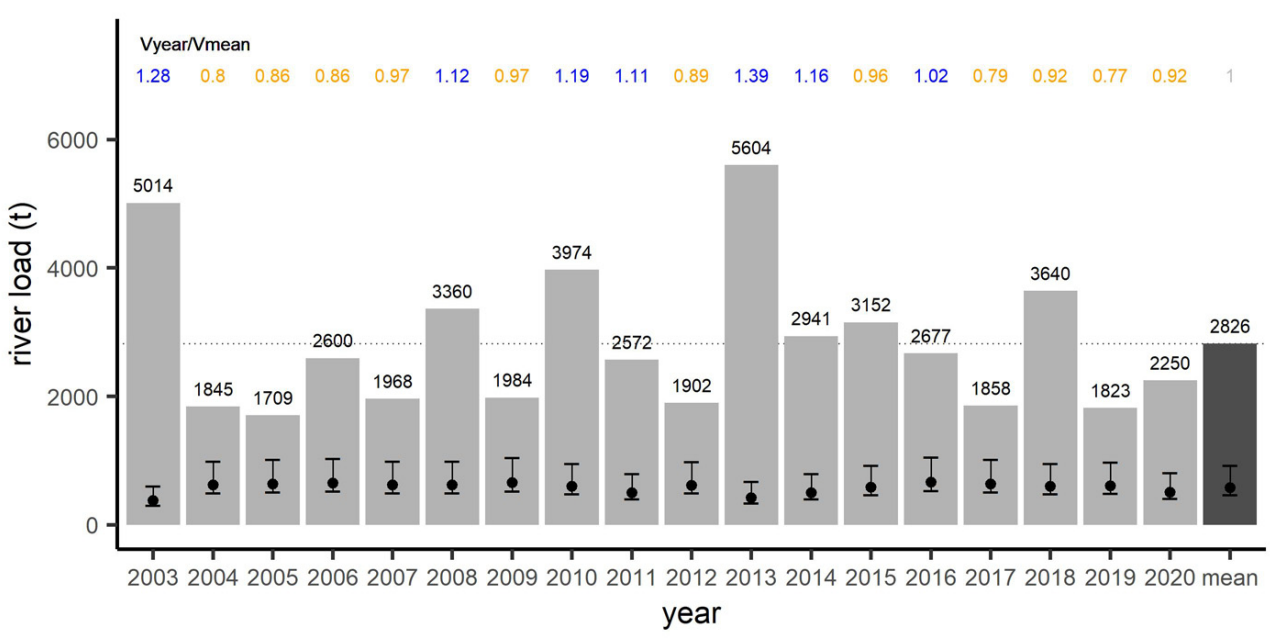

Figure 4. Annual suspended solid loads of the Kraichbach river for the years 2003-2020. Bars show the total suspended solid load, three variants of the dry-weather load calculations are shown as points (mean variant) and lines (minimum and maximum variants) in the bars. The ratio of the annual discharge volume $\left(\mathrm{V}_{\text {year }}\right)$ to the mean annual discharge volume $\left(\mathrm{V}_{\text {mean }}\right)$ is shown in blue for wet years and orange for dry years.

Based on the dry weather concentrations (median, 25th and 75th percentiles, Table 2), a range of the dry-weather load can be calculated as minimum, mean, and maximum variant. 
Points in the bars mark the calculated mean dry-weather loads and lines the minimum and maximum dry-weather loads (Figure 4). The mean dry-weather load is nearly the same over the different years (around $500 \mathrm{t}$ per year), with lowest values during flood years.

Figure 4 additionally shows the ratio of the annual discharge volume $\left(\mathrm{V}_{\text {year }}\right)$ to the mean annual discharge volume over the period of 2003-2020 $\left(\mathrm{V}_{\text {mean }}\right)$. This ratio indicates whether it is a wet (blue) or dry year (orange). The flood years of 2003 and 2013 highlight this in particular.

The mean dry-weather load varies between 467 and $925 \mathrm{t}$ per year (Table 3). The share of the mean annual suspended solids load is between 17 and $33 \%$. This means that the inputs from rain events account for more than $67 \%$ of the annual load.

Table 3. Mean annual river loads separated into dry-weather load and precipitation input.

\begin{tabular}{cccc}
\hline Parameter & \multicolumn{2}{c}{ Dry-Weather Load Variant } \\
\hline & Minimum & Mean & Maximum \\
\hline Mean annual load in $\mathrm{t} \mathrm{a}^{-1}$ & 2826 & 2826 & 2826 \\
Mean dry-weather load in $\mathrm{t} \mathrm{a}^{-1}$ & 467 & 577 & 925 \\
Mean precipitation input in $\mathrm{t} \mathrm{a}^{-1}$, total & 2359 & 2249 & 1901 \\
Thereof combined sewer overflow & 49 & 49 & 49 \\
Thereof erosion & 2310 & 2200 & 1852 \\
\hline
\end{tabular}

On average, precipitation-related sediment inputs to the Kraichbach river range between 1901 and $2359 \mathrm{t}$ per year (Table 3) comprising inputs from erosion and combined sewer overflows. The combined sewer overflows contribute approximately $49 \mathrm{t}$ per year considering a mean suspended solid concentration of $64 \mathrm{mg} \mathrm{L}^{-1}$ [70] and an annual overflow volume of $757,000 \mathrm{~m}^{3}$ per year [71].

Thus, the suspended solids inputs via erosion range from 1852 to $2310 \mathrm{t}$ per year (Table 3).

\subsection{Results of the Modeling}

The use-related results of the modeling for the factors of the USLE [23] are shown in Table 4 for the study area of the Kraichbach. The resulting long-term mean soil erosion per grid cell is shown in Figure 5 or split according to land use in Table 5. No modeling was done for use the types surface water, wetland, open land, and residential.

Table 4. USLE factors for the catchment of the Kraichbach river for different land uses.

\begin{tabular}{ccccccccc}
\hline Factor & $\begin{array}{c}\text { Arable } \\
\text { Land }\end{array}$ & $\begin{array}{c}\text { Grass- } \\
\text { Land }\end{array}$ & $\begin{array}{c}\text { Fruit } \\
\text { Growing }\end{array}$ & Viticulture & $\begin{array}{c}\text { Coniferous } \\
\text { Forest }\end{array}$ & $\begin{array}{c}\text { Deciduous } \\
\text { Forest }\end{array}$ & $\begin{array}{c}\text { Mixed } \\
\text { Forest }\end{array}$ & $\begin{array}{c}\text { Nature } \\
\text { Land }\end{array}$ \\
\hline R-factor & 88.3 & 87.5 & 90.1 & 86.6 & 86.7 & 87.9 & 86.8 & 88.1 \\
K-factor & 0.47 & 0.43 & 0.29 & 0.28 & 0.53 & 0.49 & 0.47 & 0.50 \\
LS-factor & 1.16 & 1.59 & 0.97 & 2.16 & 1.76 & 1.95 & 2.14 & 1.73 \\
C-factor & 0.085 & 0.004 & 0.19 & 0.22 & 0.002 & 0.002 & 0.002 & 0.004 \\
\hline
\end{tabular}

Table 5. Sediment input in $\mathrm{tha}^{-1}$ in the catchment of the Kraichbach river.

\begin{tabular}{ccccccccc}
\hline $\begin{array}{c}\text { Sediment Input } \\
\text { in t ha }\end{array}$ & $\begin{array}{c}\text { Arable } \\
\text { Land }\end{array}$ & $\begin{array}{c}\text { Grass- } \\
\text { Land }\end{array}$ & $\begin{array}{c}\text { Fruit } \\
\text { Growing }\end{array}$ & Viticulture & $\begin{array}{c}\text { Coniferous } \\
\text { Forest }\end{array}$ & $\begin{array}{c}\text { Deciduous } \\
\text { Forest }\end{array}$ & $\begin{array}{c}\text { Mixed } \\
\text { Forest }\end{array}$ & $\begin{array}{c}\text { Nature } \\
\text { Land }\end{array}$ \\
\hline Mean & 0.478 & 0.009 & 0.638 & 2.08 & 0.003 & 0.004 & 0.003 \\
SD & 1.19 & 0.035 & 1.11 & 4.56 & 0.023 & 0.023 & 0.022 \\
Min & 0.000 & 0.000 & 0.000 & 0.000 & 0.000 & 0.000 & 0.000 & 0.036 \\
Max & 82.9 & 3.69 & 6.96 & 134 & 0.57 & 0.98 & 1.29 & 0.80 \\
\hline
\end{tabular}




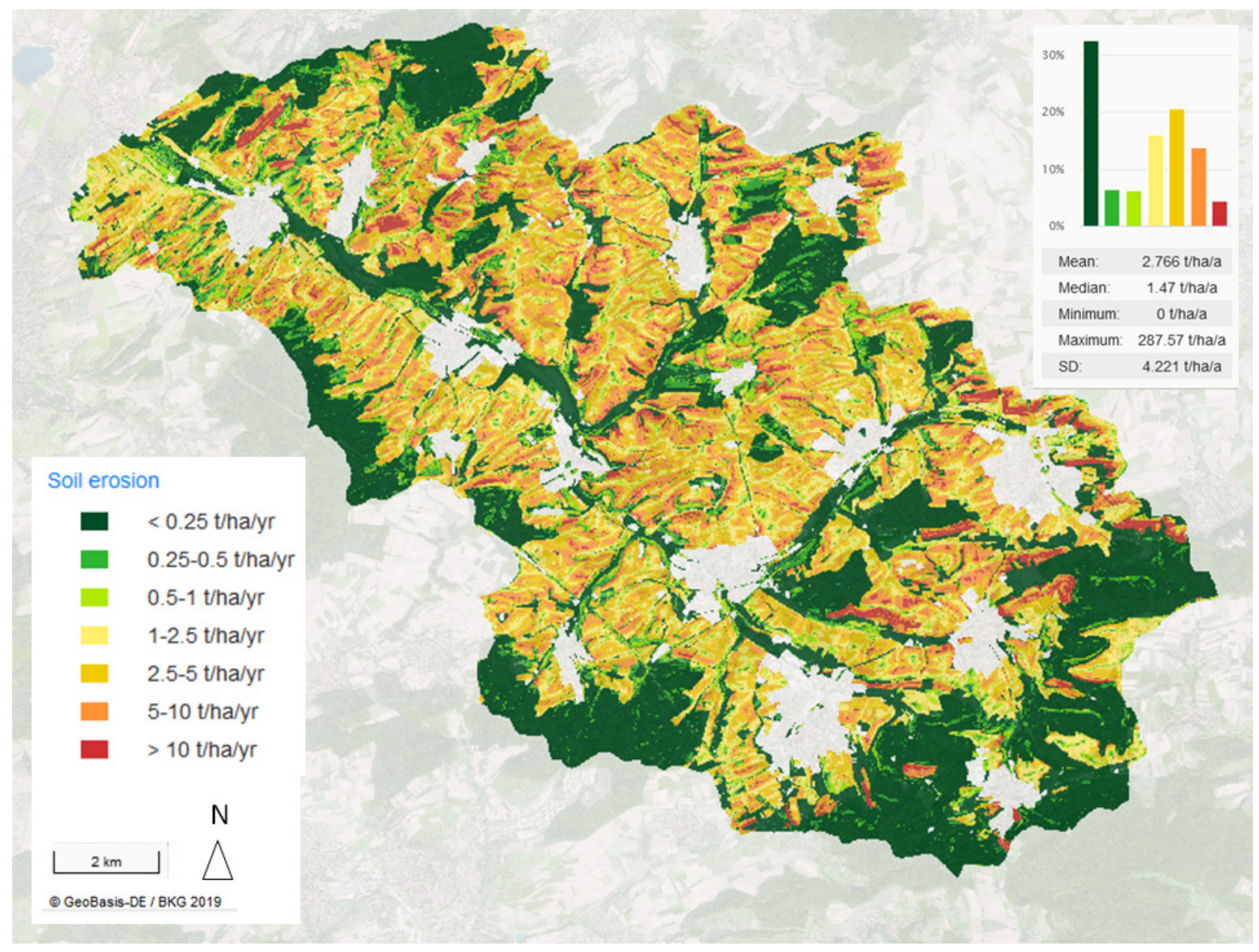

Figure 5. Modeled soil loss in the Kraichbach catchment.

An overview of the mean watercourse distances, connectivity probabilities and the resulting long-term mean sediment inputs are given in Figures 5-8. Areas not filled in with color are covered by land use types for which no soil erosion and sediment input modeling was carried out or which are not hydrologically connected and thus do not contribute to the sediment input. Thus, it can be assumed that only a small fraction of eroded soil material is carried into surface waters. At the same time, the input of sediment and particle-bound nutrients is largely limited to only a few small subcatchments [58]. Causes include watercourse distances and the transport power of surface water runoff, as well as deposition and accumulation of eroded soil in the terrain.

The mean land-use-related sediment inputs are listed in Table 5. Table 6 shows a comparison of soil erosion totals or sediment input totals in the Kraichbach river study area by land use type.

Table 6. Soil loss and sediment input in t per year in the catchment of the Kraichbach river.

\begin{tabular}{cccccccccc}
\hline Sum in $\mathbf{t ~ a ~}^{-\mathbf{1}}$ & $\begin{array}{c}\text { Arable } \\
\text { Land }\end{array}$ & $\begin{array}{c}\text { Grass- } \\
\text { Land }\end{array}$ & $\begin{array}{c}\text { Fruit } \\
\text { Growing }\end{array}$ & Viticulture & $\begin{array}{c}\text { Coniferous } \\
\text { Forest }\end{array}$ & $\begin{array}{c}\text { Deciduous } \\
\text { Forest }\end{array}$ & $\begin{array}{c}\text { Mixed } \\
\text { Forest }\end{array}$ & $\begin{array}{c}\text { Nature } \\
\text { Land }\end{array}$ & $\begin{array}{c}\text { Total } \\
\text { Soil loss }\end{array}$ \\
32,192 & 457.7 & 297.7 & 6286 & 16.3 & 228.1 & 217.3 & 157.4 & 39,853 \\
$\begin{array}{c}\text { Sediment } \\
\text { input }\end{array}$ & 1460 & 7.2 & 5.3 & 158.5 & 0.2 & 2.1 & 1.2 & 3.3 & 1638 \\
\hline
\end{tabular}




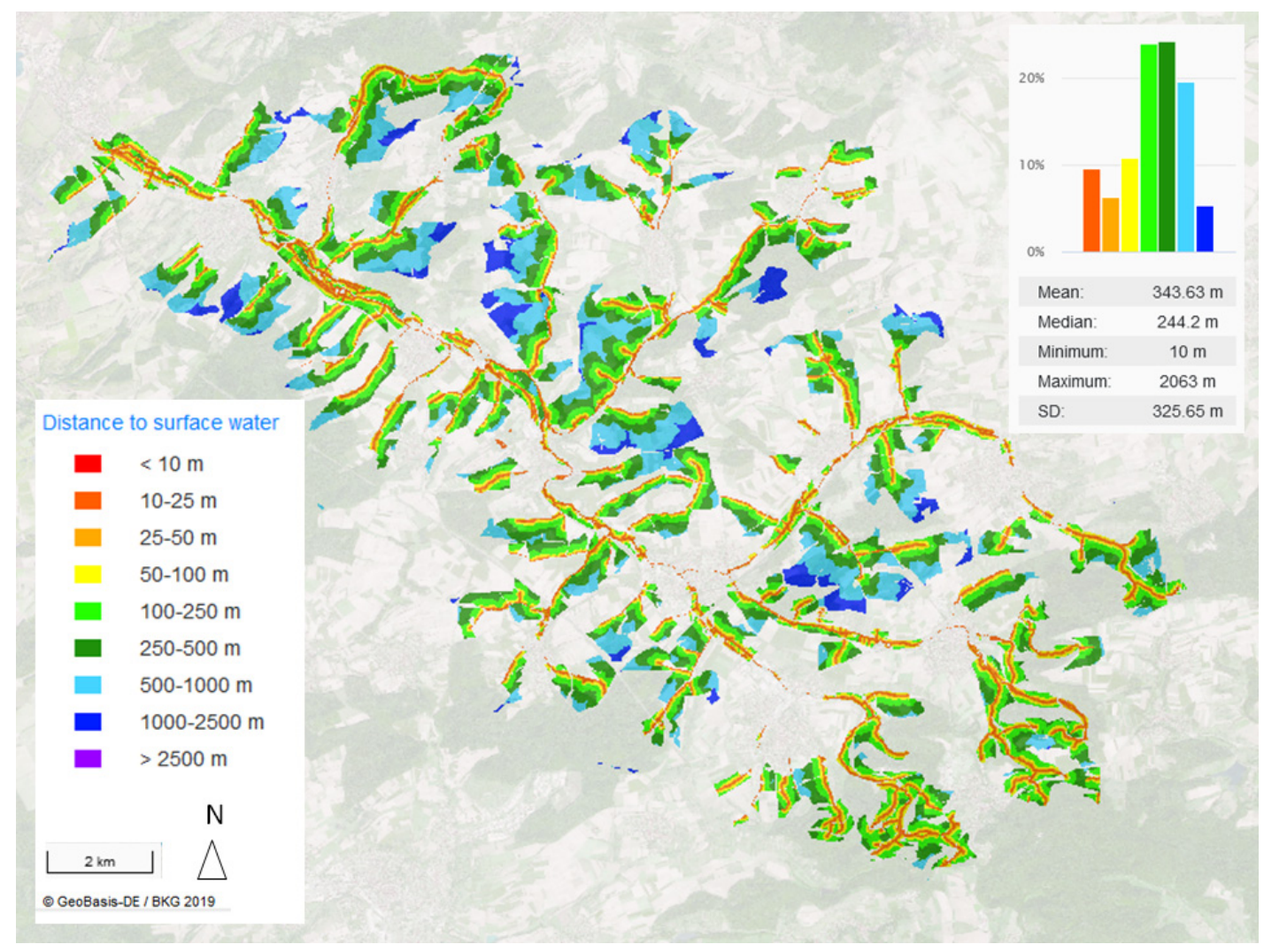

Figure 6. Modeled distance to water surface in the Kraichbach catchment.

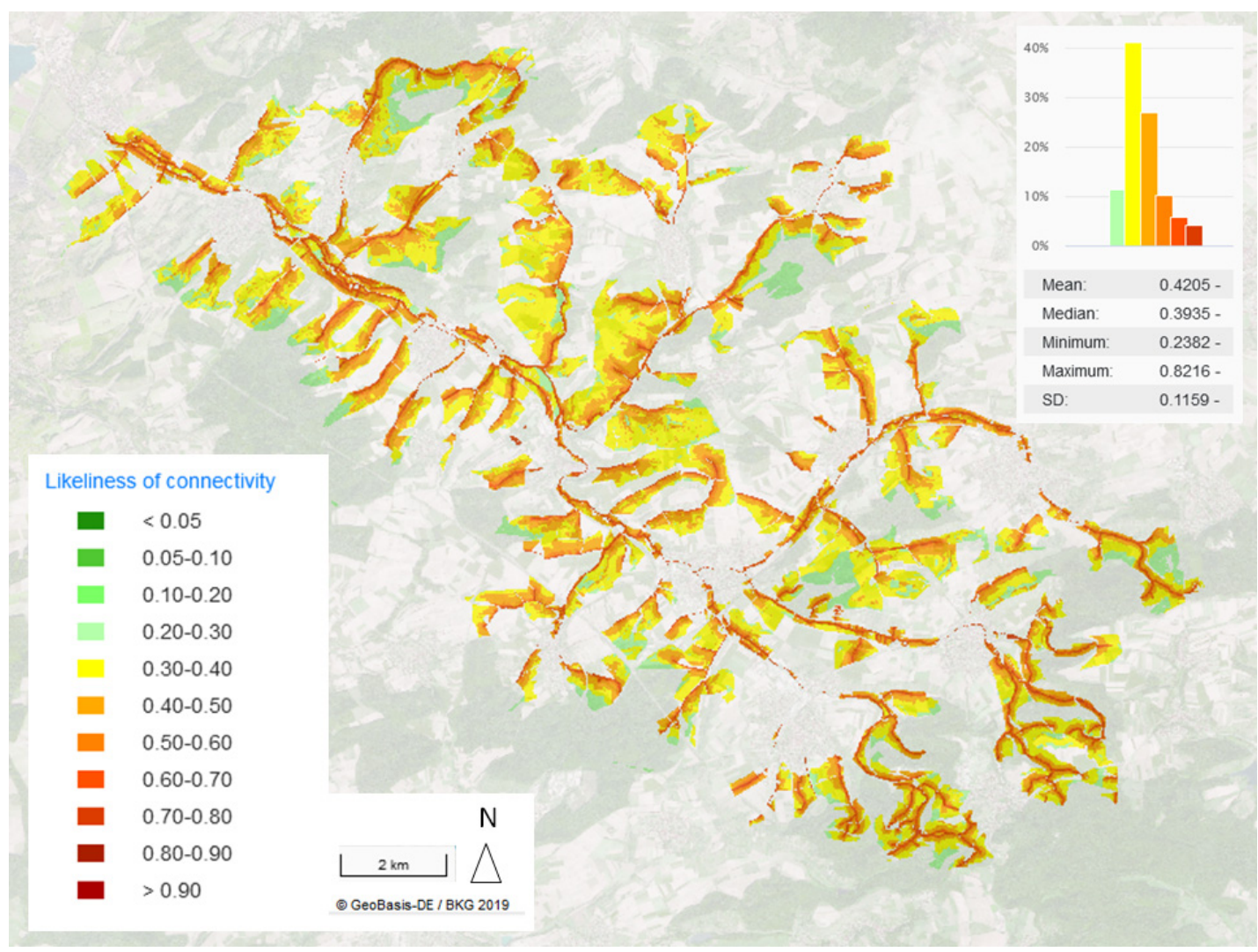

Figure 7. Modeled connectivity probability in the Kraichbach catchment. 


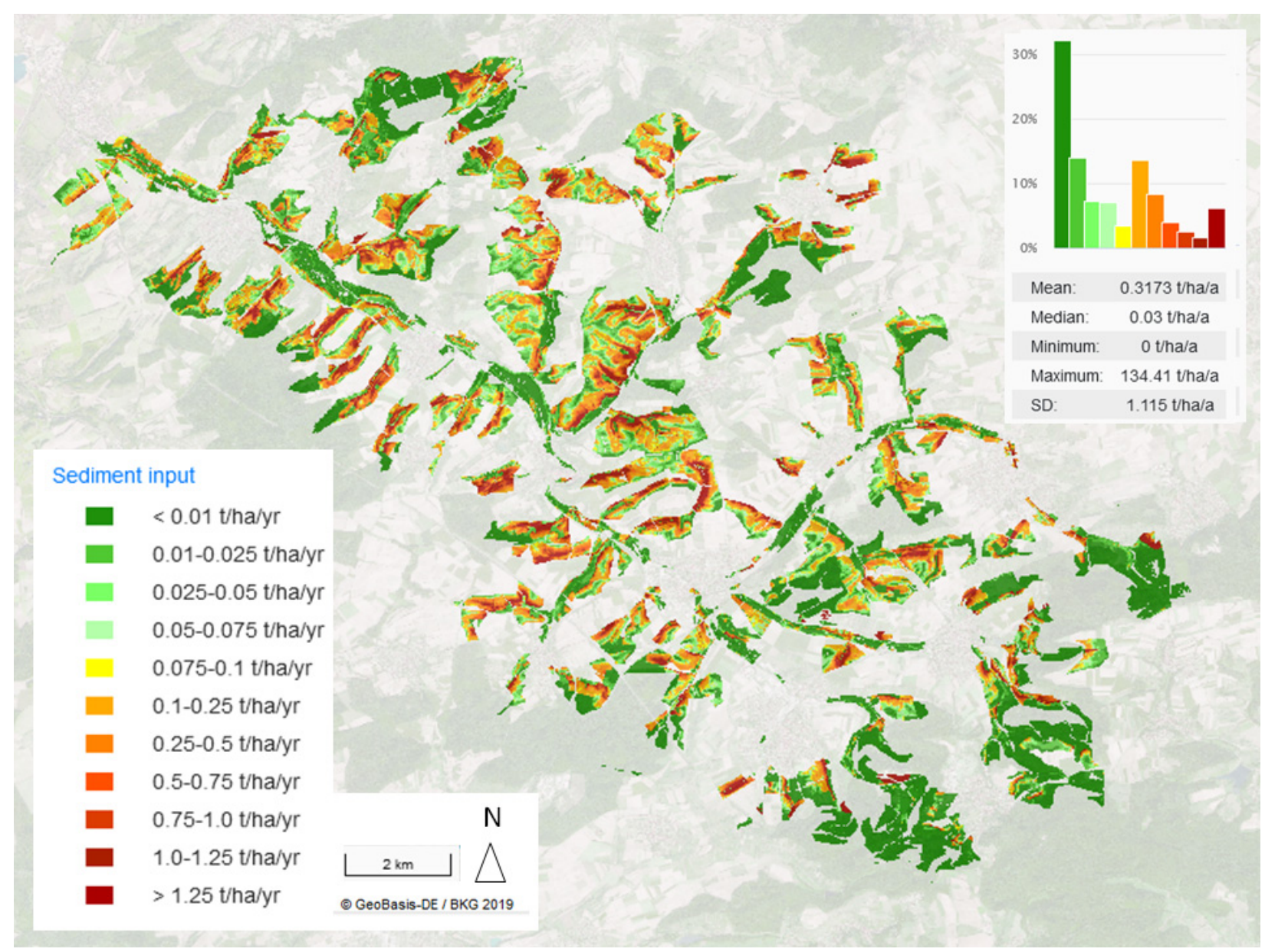

Figure 8. Modeled sediment input in the Kraichbach catchment.

The total sum of the modeled long-term mean sediment input in the Kraichbach catchment is thus $1638 \mathrm{t}$ per year.

\section{Discussion}

The use of large-volume samplers is well suitable to capture particulate-transported materials. Long-term runoff proportional sampling provides the opportunity to represent the runoff dynamics of a river properly. According to Horowitz [20], 80-85\% of the annual runoff events should be covered during sampling to provide representative annual loads. For particulate-bound substances such as phosphorus, which are mobilized and transported in the water body during high discharges, the loads in the water body are recorded more realistically with large-volume composite samples over several days than with single samples [19].

The rating curve exists out of four years of monitoring data representing a robust mean state of the river by considering different hydrological situations of the sampled years. Horowitz [20] points out that the stationarity should be checked when using sediment rating curves for estimating river loads. Stationarity of a system means that only little or no changes in sources or relations occur [20]. During the sampling period, stationarity is given, therefore, the rating curve can be used to calculate mean annual loads in this period. Extrapolation to long-term discharges (2003-2020) may have uncertainties as during this long period dynamics in hydrology, land use, and population appear. In our study, this fact is not considered, as a long-term mean river load is needed for comparison with the modeled sediment input. 
Errors may also occur during sample collection and preparation. By analyzing all samples in the same laboratory and following a strict sampling protocol since 2017, we try to minimize the errors related to the methodology.

Allion et al. [34] describe that there are further uncertainties in the load calculation caused the small number of samples at high discharges. This significantly affects the shape of the rating curve. The problem is also described by Horowitz [72], who points out that this causes rating curves to underestimate high solids concentrations and overestimate low concentrations. Additional samples at high discharges would be desirable, but are difficult to capture due to low occurrence.

The method of separating a dry-weather load is also subject to uncertainty. There is currently no precise definition and it is clear that rain events can also occur in the low runoff range. Rain events occurring sporadically and in a small part of the catchment may result in increased suspended solid concentrations without a clearly visible reaction of the river flow. In addition, the internal processes and the remobilization of solids in the water body cannot be identified and mapped with the LVS.

In the modeling, it must be taken into account that the modeled erosive sediment inputs are based on soil erosions, which represent long-term average values and only cover the sheet and rill erosion paths. Thus, channel and gully erosion is explicitly not included. According to Fischer et al. [73] and Brandhuber et al. [74], it can be assumed that the importance of these erosion forms in the input event is increasing due to climate change, even though they were practically not observed in Bavaria, for example, until 30 years ago. In addition, event-driven solid inputs from residential areas (e.g., runoff from construction sites, from industrial and commercial sites, brownfields, traffic areas, etc.) are not included in the modeling, although these input pathways are likely to be of marginal importance in the rural study area [75].

In the following classification of the model results for sediment input in comparison to the measured suspended solid loads, it should be noted that the measured solid load is supplied by erosion, but also by a dry-weather load that should not be underestimated. This is not erosion controlled and is continuously recorded even during dry weather runoff or mean flow. This dry-weather load was determined in the present study and must necessarily be added to the modeled loads for validation of an erosion-controlled sediment input. Dry-weather loads are fed from in-water processes such as deep and lateral erosion, direct input of solids (e.g., leaf fall) and solids inputs from wastewater treatment plants. As mentioned earlier, event-driven solids inputs from residential areas, including solids inputs from combined sewer overflows, are not included either. Thus, considering these unaccounted sources, the modeled sediment input should be lower than the measured solids load minus the dry-weather load.

For the dry-weather load (including wastewater treatment plant emissions), expected as a long-term average, a corridor of 467 to $925 \mathrm{t}$ per year results, as discussed in Section 3.2. This leaves 1852 to $2310 \mathrm{t}$ per year for the erosion-driven input, if the likewise event-driven combined sewer overflow (49 t per year, see Section 3.2) is subtracted.

According to the modeling of the long-term mean sediment input, $1638 \mathrm{t}$ per year result. In order to describe the erosive inputs completely the missing erosion rates from channel and gully erosion as well as from erosive inputs from the settlement area have to be added. The contribution of channel or gully erosion to the total erosive input can be roughly estimated at 12 to $29 \%$ for arable land [76,77]. Based on permanent observation plots in Lower Saxony, combined with modeling of surface erosion, linear erosion (including rill erosion) accounts for $25 \%$ of total erosion on average for all considered plots [77-79]. Thus, an increase in the sediment input of $1638 \mathrm{t}$ per year modeled here by a factor of 1.1 to 1.2 seems justified in order to approximately cover the shares of channel and gully erosion as well as other runoff not considered (e.g., from settlement areas). Thus, a comparative value of approx. Sediment input is 1800 to $2000 \mathrm{t}$ per year, which almost perfectly fits into the measured corridor of the sediment loads recorded in the water body via the continuously operating LVS minus the dry-weather load and combined sewer discharge 
(1852 to $2310 \mathrm{t}$ per year). It should also be noted that the proportion of linear erosion such as channel or gully erosion in the years with particularly high discharges $(2003,2013)$ is likely to be significantly higher than the 10-20\% estimated here, and the USLE [23] tend to significantly underestimate soil erosion in these years.

\section{Conclusions}

Within the framework of the work presented here, it can be shown that the tools used to model the long-term mean sediment input provide plausible results in comparison with the suspended solid loads recorded via continuous LVS sampling and under consideration of the dry-weather load. It can be assumed that the model approach used here, which has already been successfully applied in many other studies [11,12,32,60-63], can provide valid results for solid input, especially for areas with a high importance of particulate substance input. The use of the approach for a nationwide modeling of soil erosion and sediment input seems justified under consideration of the positive validation. Nevertheless, the algorithms used here contain uncertainties and represent the process of erosion up to the input of sediment only in a simplified way. In the future, the recording of sediment loads with continuously operating LVS should be extended to further test areas with deviating catchment characteristics in order to expand the data basis for the verification of model results. The focus should be to take long-term composite samples over a long period of time.

Currently, a project funded by the Federal Environment Agency (FKZ 3719212020) entitled "Further development of Germany-wide balancing of inputs of trace substances and evaluation of reduction measures" is in progress. In this project, LVS are used in a river catchment at surface waters, combined sewer overflows, and storm water discharges in order to gain further knowledge about sediment transport and sources.

The transferability of the modeling approach presented here to other areas in Germany and neighboring regions and its forecast quality with regard to the comparison of measured and modeled solid loads can thus be successively improved. However, the approaches focus on long-term modeling of soil erosion and particle bound solids input to support water resource management on a regional level, so that event-related phenomena at high temporal resolution are not covered. This is not planned in large areas such as the Federal Republic of Germany and would also necessitate a shift to more physically based modeling approaches [44,80], for which, however, there is insufficient available data at the regional level.

To step by step enable the traceability of the model results and to facilitate the comparison with the results of other model approaches, all results are integrated into a web-based publicly accessible portal. The data can be analyzed on this platform for the Kraichbach area as well as in nationwide grid-based form or aggregated to different spatial levels and are also available for download for other user groups.

Author Contributions: Conceptualization, K.A. and M.G.; methodology, K.A. and M.G.; software, M.G., M.U., S.H. and S.B.; validation, K.A. and M.G.; investigation, K.A, M.G., M.U., S.H., S.B. and L.K.; data curation, K.A., L.K., M.G., M.U., S.H. and S.B.; writing-original draft preparation, K.A. and M.G.; writing-review and editing, S.F.; visualization, K.A., L.K. and M.G.; supervision, S.F.; project administration, S.F.; funding acquisition, S.F. All authors have read and agreed to the published version of the manuscript.

Funding: This research was funded by the German Federal Environment Agency, grant number 3718722110, and the State Institute for the Environment, Measurements and Conservation of BadenWuerttemberg (LUBW). We acknowledge support by the KIT Publication Fund of the Karlsruhe Institute of Technology.

Institutional Review Board Statement: Not applicable.

Informed Consent Statement: Not applicable. 
Data Availability Statement: The modeled data presented in this study are openly available at https: / /visdat.de/viewer_sediment (accessed on 17 December 2021). The data of the LVS is available as Supplementary Material in Allion et al. [34].

Acknowledgments: We would like to thank our student assistants for the sampling on the Kraichbach in all different kinds of weather. Further thanks go to Jan Philip Nickel for his comments on the draft of the manuscript.

Conflicts of Interest: The authors declare no conflict of interest. The funders had no role in the design of the study; in the collection, analyses, or interpretation of data; in the writing of the manuscript, or in the decision to publish the results.

\section{References}

1. Directive 2000/60/EC of the European Parliament and of the Council of 23 October 2000 Establishing a Framework for Community Action in the Field of Water Policy: WFD, 2000. Available online: https://eur-lex.europa.eu/legal-content/en/ALL/?uri= CELEX\%3A32000L0060 (accessed on 17 December 2021).

2. Bundesregierung Deutschland. Oberflächengewässerverordnung (Verordnung zum Schutz der Oberflächengewässer) vom 20. Juni 2016: OGewV, 2016. Available online: http://www.gesetze-im-internet.de/ogewv_2016/OGewV.pdf (accessed on 17 December 2021).

3. Lemm, J.U.; Venohr, M.; Globevnik, L.; Stefanidis, K.; Panagopoulos, Y.; Gils, J.; Posthuma, L.; Kristensen, P.; Feld, C.K.; Mahnkopf, J.; et al. Multiple stressors determine river ecological status at the European scale: Towards an integrated understanding of river status deterioration. Glob. Chang. Biol. 2021, 27, 1962-1975. [CrossRef] [PubMed]

4. European Commission. Report from the Commission to the Eurpean Parliament and the Council on the Implementation of the Water Framework Directive (2000/60/EC) and the Floods Directive (2007/60/EC). Available online: https:/ / eur-lex.europa.eu/ legal-content/EN/TXT/HTML/?uri=COM:2019:95:FIN\&from=EN (accessed on 17 December 2021).

5. $\quad$ Fuchs, S.; Weber, T.; Wander, R.; Toshovski, S.; Kittlaus, S.; Reid, L.; Bach, M.; Klement, L.; Hillenbrand, T.; Tettenborn, F. Effizienz von Maßnahmen zur Reduktion von Stoffeinträgen, 1st ed.; Endbericht; Umweltbundesamt: Dessau-Roßlau, Germany, 2017.

6. Fuchs, S.; Rothvoß, S.; Toshovski, S. Ubiquitäre Schadstoff-Eintragsinventare, Umweltverhalten und Eintragsmodellierung: Abschlussbericht (Forschungskennzahl 371421200 0). TEXTE 52/2018. 2018. Available online: https:/ / www.umweltbundesamt. de/publikationen/ubiquitaere-schadstoffe-eintragsinventare (accessed on 17 December 2021).

7. Abdelwahab, O.M.M.; Bisantino, T.; Milillo, F.; Gentile, F. Runoff and sediment yield modeling in a medium-size mediterranean watershed. J. Agric. Eng. 2013, 44. [CrossRef]

8. Arnold, J.G.; Moriasi, D.N.; Gassman, P.W.; Abbaspour, K.C.; White, M.J.; Srinivasan, R.; Santhi, C.; Harmel, R.D.; van Griensven, A.; van Liew, M.W.; et al. SWAT: Model Use, Calibration, and Validation. Trans. ASABE 2012, 55, 1491-1508. [CrossRef]

9. Ta, P.; Tetzlaff, B.; Trepel, M.; Wendland, F. Implementing a Statewide Deficit Analysis for Inland Surface Waters According to the Water Framework Directive-An Exemplary Application on Phosphorus Pollution in Schleswig-Holstein (Northern Germany). Water 2020, 12, 1365. [CrossRef]

10. Fuchs, S.; Kaiser, M.; Kiemle, L.; Kittlaus, S.; Rothvoß, S.; Toshovski, S.; Wagner, A.; Wander, R.; Weber, T.; Ziegler, S. Modeling of Regionalized Emissions (MoRE) into Water Bodies: An Open-Source River Basin Management System. Water 2017, 9, 239. [CrossRef]

11. Gebel, M.; Uhlig, M.; Halbfass, S.; Meissner, R.; Duan, S. Predicting erosion and sediment yield in a mesoscale basin in the semiarid monsoon region Miyun/China. Ecol. Process. 2014, 3, 39. [CrossRef]

12. Gebel, M.; Bürger, S.; Wallace, M.; Malherbe, H.; Vogt, H.; Lorz, C. Simulation of land use impacts on sediment and nutrient transfer in coastal areas of Western Cape, South Africa. Chang. Adapt. Socio-Ecol. Syst. 2017, 3, 1-17. [CrossRef]

13. Tetzlaff, B.; Wendland, F. Modelling Sediment Input to Surface Waters for German States with MEPhos: Methodology, Sensitivity and Uncertainty. Water Resour Manag. 2012, 26, 165-184. [CrossRef]

14. Behrendt, H.; Huber, P.; Kornmilch, M.; Opitz, D.; Schmoll, O.; Scholz, G.; Uebe, R. Nutrient Emissions into River Basins, 1st ed.; Federal Environment Agency (Umweltbundesamt): Berlin, Germany, 2000.

15. Venohr, M.; Hirt, U.; Hofmann, J.; Opitz, D.; Gericke, A.; Wetzig, A.; Natho, S.; Neumann, F.; Hürdler, J.; Matranga, M.; et al. Modelling of Nutrient Emissions in River Systems-MONERIS-Methods and Background. Int. Rev. Hydrobiol. 2011, 96, 435-483. [CrossRef]

16. Borrelli, P.; van Oost, K.; Meusburger, K.; Alewell, C.; Lugato, E.; Panagos, P. A step towards a holistic assessment of soil degradation in Europe: Coupling on-site erosion with sediment transfer and carbon fluxes. Environ. Res. 2018, 161, 291-298. [CrossRef]

17. Schmidt, B.; Kuhn, U.; Trepel, M.; Kreins, P.; Zinnbauer, M.; Eysholdt, M.; Osterburg, B.; Löw, P.; Wendland, F.; Herrmann, F.; et al. Modellansatz zur Bestimmung der Nährstoffbelastung und ihrer Reduktion in allen deutschen Flussgebieten. Wasser Und Abfall 2020, 22, 33-38. [CrossRef]

18. Binger, R.L.; Theurer, F.D. AGNPS Web Site. Available online: http://www.ars.usda.gov/Research/docs.htm?docid=5199 (accessed on 25 October 2021). 
19. Hilden, M. Ermittlung von Stoff-Frachten in Fliessgewässern: Probenahmestrategien und Berechnungsverfahren; Kulturbuch-Verl.: Berlin, Germany, 2003; ISBN 3889612423.

20. Horowitz, A.J. A review of selected inorganic surface water quality-monitoring practices: Are we really measuring what we think, and if so, are we doing it right? Environ. Sci. Technol. 2013, 47, 2471-2486. [CrossRef] [PubMed]

21. Schreiber, W.; Krauss-Kalweit, I. Frachten von Wasserinhaltsstoffen in Fließgewässern-Einfluß der Probenahmestrategie auf die Ermittlung. Wasserwirtschaft 1999, 89, 520-645.

22. Panagos, P.; Borrelli, P.; Poesen, J.; Ballabio, C.; Lugato, E.; Meusburger, K.; Montanarella, L.; Alewell, C. The new assessment of soil loss by water erosion in Europe. Environ. Sci. Policy 2015, 54, 438-447. [CrossRef]

23. Wischmeyer, W.H.; Smith, D.D. Predicting Rainfall Erosion Losses. A Guide to Conservation Planning; The USDA Agricultural Handbook No. 537; The USDA: Annapolis, MD, USA, 1978.

24. Wurbs, D.; Steininger, M. Wirkungen der Klimaänderungen auf die Böden: Untersuchungen zu den Auswirkungen des Klimawandels auf die Bodenerosion durch Wasser; Umweltbundesamt: Dessau-Roßlau, Germany, 2011.

25. Bundesanstalt für Geowissenschaften und Rohstoffe. Potentielle Erosionsgefährdung der Ackerböden durch Wasser in Deutschland: Herausgegeben von der Bundesanstalt für Geowissenschaften. Available online: https://www.bgr.bund.de/DE/Themen/ Boden/Ressourcenbewertung/Bodenerosion/Wasser/PEGWasser_Handzettel_de.pdf?_blob=publicationFile\&v=1 (accessed on 25 October 2021).

26. Plambeck, N.O. Reassessment of the potential risk of soil erosion by water on agricultural land in Germany: Setting the stage for site-appropriate decision-making in soil and water resources management. Ecol. Indic. 2020, 118, 106732. [CrossRef]

27. Auerswald, K.; Fischer, F.K.; Winterrath, T.; Brandhuber, R. Rain erosivity map for Germany derived from contiguous radar rain data. Hydrol. Earth Syst. Sci. 2019, 23, 1819-1832. [CrossRef]

28. Auerswald, K.; Ebertseder, F.; Levin, K.; Yuan, Y.; Prasuhn, V.; Plambeck, N.O.; Menzel, A.; Kainz, M. Summable C factors for contemporary soil use. Soil Tillage Res. 2021, 213, 105155. [CrossRef]

29. Prasuhn, V. Twenty years of soil erosion on-farm measurement: Annual variation, spatial distribution and the impact of conservation programmes for soil loss rates in Switzerland. Earth Surf. Process. Landf. 2020, 45, 1539-1554. [CrossRef]

30. Poesen, J. Soil erosion in the Anthropocene: Research needs. Earth Surf. Process. Landf. 2018, 43, 64-84. [CrossRef]

31. Gebel, M.; Allion, K.; Plambeck, N.O.; Fuchs, S.; Ullrich, A. Deutschlandweite hochaufgelöste Modellierung von Sedimenttransfers in die Oberflächengewässer zur Ableitung partikelgebundener Phosphoreinträge. KW—Korrespondenz Wasserwirtschaft. 2021, 14, 413-417.

32. Gebel, M.; Bürger, S.; Halbfass, S.; Uhlig, M. Modellgestützte Ermittlung der Nährstoffeinträge in sächsische Gewässer: Status quo und Ausblick bis 2027. Available online: https://publikationen.sachsen.de/bdb/artikel/11373 (accessed on 15 October 2021).

33. Wagner, A. Event-Based Measurement and Mean Annual Flux Assessment of Suspended Sediment in Meso Sclae Catchments. Dissertation; Karlsruher Institut für Technologie: Karlsruhe, Germany, 2019.

34. Allion, K.; Kiemle, L.; Fuchs, S. Four years of sediment and phosphorus monitoring in the Kraichbach river using large-volume samplers. Water 2021. submitted.

35. Fuchs, S.; Mayer, I.; Haller, B.; Roth, H. Lamella settlers for storm water treatment-performance and design recommendations. Water Sci. Technol. 2014, 69, 278-285. [CrossRef] [PubMed]

36. Kemper, M.; Eyckmanns-Wolters, R.; Fuchs, S.; Ebbert, S.; Maus, C.; Uhl, M.; Weiß, G.; Nichler, T.; Engelberg, M.; Gillar, M.; et al. Analyse der Leistungsfähigkeit von Regenüberlaufbecken und Überwachung durch Online Messtechnik; Abschlussbericht, 2015. Available online: http:/ / www.lanuv.nrw.de/uploads/tx_mmkresearchprojects/2015_12_16_Schlussbericht_Monitoring.pdf (accessed on 26 January 2016).

37. Nickel, J.P.; Fuchs, S. Micropollutant emissions from combined sewer overflows. Water Sci. Technol. 2019, 80, 2179-2190. [CrossRef]

38. Nickel, J.P.; Fuchs, S. Large-Volume Samplers for Efficient Composite Sampling and Particle Characterization in Sewer Systems. Water 2021, 13, 2831. [CrossRef]

39. Toshovski, S.; Kaiser, M.; Fuchs, S.; Sacher, F.; Thoma, A.; Kümmel, V.; Lambert, B. Prioritäre Stoffe in kommunalen Kläranlagen: Ein deutschlandweit harmonisiertes Vorgehen; TEXTE 173/2020, Dessau-Roßlau, 2020. Available online: https:/ / www. umweltbundesamt.de/publikationen/prioritaere-stoffe-in-kommunalen-klaeranlagen (accessed on 8 December 2020).

40. Fuchs, S.; Wander, R.; Rogozina, T.; Hilgert, S.; Scherer, U. Methodische Optimierung von Modellansätzen zur Schadstoffbilanzierung in Flussgebietseinheiten zur Förderung der Umsetzungsstrategie zur Wasserrahmenrichtlinie: Endbericht für das Vorhaben FZK: 370822 202/01, Karlsruhe, 2012. Available online: http:/ / digbib.ubka.uni-karlsruhe.de/volltexte/1000051892 (accessed on 17 December 2021).

41. Fuchs, S.; Butz, J.; Bechtel, A. Stoffstromanalysen für kleine bis mittlere Flussgebiete als Grundlage für die Planung und Umsetzung von Gewässerschutzmaßnahmen: Forschungsbericht FZKA-BWPLUS, 2004. Available online: https://pudi.lubw.de/ detailseite/- / publication/74744 (accessed on 17 December 2021).

42. Schwertmann, U.; Vogl, W.; Kainz, M. Bodenerosion durch Wasser: Vorhersage des Abtrags und Bewertung von Gegenmaßnahmen, 2nd ed.; Ulmer: Stuttgart, Germany, 1990; ISBN 9783800130887.

43. Schmidt, J. Entwicklung und Anwendung eines Physikalisch Begründeten Simulationsmodells für die Erosion Geneigter landwirtschaftlicher Nutzflächen; Selbstverl. des Inst. für Geograph. Wiss.: Berlin, Germany, 1996. 
44. Schob, A.; Schmidt, J.; Tenholtern, R. Derivation of site-related measures to minimise soil erosion on the watershed scale in the Saxonian loess belt using the model EROSION 3D. Catena 2006, 68, 153-160. [CrossRef]

45. Kinnell, P.I.A. The USLE-M and Modeling Erosion within Catchments. In Sustaining the Global Farm. Selected papers from the 10th International Soil Conservation Organization on Meeting held May 24-29, 1999 at Perdue University and the USDA-ARS National Soil Erosion Research Laboratory; Stott, D.E., Mohtar, R.H., Steinhardt, G.C., Eds.; International Soil Conservation Organization (ISCO): West Lafayette, IN, USA, 2001; pp. 924-928.

46. Auerswald, K.; Schwertmann, U. Modelle zur Erosionsvorhersage als Entscheidungsgrundlage des Bodenschutzes. Bodenschutz 1988, 30, 233-241.

47. Fischer, F.K.; Winterrath, T.; Junghänel, T.; Walawender, E.; Auerswald, K. Mean Annual Precipitation Erosivity (R Factor) Based on RADKLIM. Version 2017.002. 2019. Available online: https:/ / doi.org/10.5676/DWD/RADKLIM_Rfct_V2017.002 (accessed on 17 December 2021).

48. Sauerborn, P. Die Erosivität der Niederschläge in Deutschland-Ein Beitrag zur quantitaiven Prognose der Bodenerosion durch Wasser in Mitteleuropa. Ph.D. Thesis, Leibniz University, Hannover, Germany, 1994.

49. Bundesanstalt für Geowissenschaften und Rohstoffe. Bodenübersichtskarte der Bundesrepublik Deutschland 1:200.000 (BÜK200); Bundesanstalt für Geowissenschaften und Rohstoffe (BGR): Hannover, Germany, 2018.

50. Renard, K.G.; Foster, G.R.; Weesies, G.A.; Mccool, D.K.; Yoder, D.C. Predicting Soil Erosion by Water: A guide to Conservation Planning with the Revised Universal Soil Loss Equation (RUSLE); Agriculture Handbook No. 703; The USDA: Annapolis, MD, USA, 1997.

51. Moore, I.D.; Nieber, J.L. Landscape assessment of soil erosion and nonpoint source pollution. J. Minnesota Acad. Sci. 1989, 55, 18-25.

52. Hrabalíková, M.; Janeček, M. Comparison of different approaches to LS factor calculations based on a measured soil loss under simulated rainfall. Soil Water Res. 2017, 12, 69-77. [CrossRef]

53. Desmet, P.J.J.; Govers, G. A GIS procedure for automatically calculating the USLE LS factor on topographically complex landscape units. J. Soil Water Conserv. 1996, 51, 427-433.

54. Destatis. Land-und Forstwirtschaft, Fischerei: Bodenbearbeitung, Erosionsschutz, Fruchtwechsel/Agrarstrukturerhebung. Available online: https://www.destatis.de/DE/Themen/Branchen-Unternehmen/Landwirtschaft-Forstwirtschaft-Fischerei/ Produktionsmethoden/Publikationen/Downloads-Produktionsmethoden/bodenbearbeitung-erosionsschutz-fruchtwechsel5411209169004.html (accessed on 17 December 2021).

55. EUROSTAT. Statistics Explained: Agri-environmental Indicator-Tillage Practices. Available online: https://ec.europa.eu/ eurostat/statistics-explained/index.php/Agri-environmental_indicator_-_tillage_practices\#Analysis_at_regional_level (accessed on 15 October 2021).

56. Panagos, P.; Borrelli, P.; Meusburger, K.; Alewell, C.; Lugato, E.; Montanarella, L. Estimating the soil erosion cover-management factor at the European scale. Land Use Policy 2015, 48, 38-50. [CrossRef]

57. Wu, S.; Li, J.; Huang, G. An evaluation of grid size uncertainty in empirical soil loss modeling with digital elevation models. Env. Model Assess 2005, 10, 33-42. [CrossRef]

58. Voges, J. Empirisches Modell für die mittlere Maßstabsebene zur GIS-Gestützten Bestimmung der Anbindung Erosionsgefährdeter Ackerflächen. Ph.D. Thesis, Hannover Universität, Hannover, Germany, 1999.

59. Veith, T. Agricultural BMP Placement for Cost-Effective Pollution Control at the Watershed Level; Virginia Polytechnic Institute and State University: Black Fort, VA, USA, 2002.

60. Halbfass, S. Entwicklung eines GIS-gestützten Modells zur Quantifizierung Diffuser Phosphoreinträge in Oberflächengewässer im Mittleren Maßstab unter Berücksichtigung Geoökologisch Wirksamer Raumstrukturen; Rhombos-Verl.: Berlin, Germany, 2005 ; ISBN 3937231765.

61. Halbfass, S.; Grunewald, K. Abschätzung potenzieller Herkunftsflächen von erosionsbedingten Stoffeinträgen in Oberflächengewässer im mittleren Maßstab. Wasserwirtschaft 2006, 96, 24-28. [CrossRef]

62. Halbfass, S.; Grunewald, K. Ermittlung räumlich verteilter SDR-Faktoren zur Modellierung von Sedimenteinträgen in Fließgewässer im mittleren Maßstab. Wasserwirtschaft 2008, 3, 31-35.

63. Mitigation Options for Nutrient Reduction in Surface Water and Groundwaters: Proposal for a New COST Action, COST Action 869. In Proceedings of the 164th CSO Meeting, Brussels, Belgium, 29-30 March 2006.

64. Bundesamt für Kartographie und Geodäsie. Digitales Geländemodell für Deutschland im 10-m-Raster; DGM10/BKG/2017; Bundesamt für Kartographie und Geodäsie: Frankfurt am Main, Germany, 2017.

65. Bundesamt für Kartographie und Geodäsie. Digitales Basis-Landschaftsmodell 2016 (AAA-Modellierung). Bundesrepublik Deutschland: UTM-Abbildung in der Zone 32 und 33; Bundesamt für Kartographie und Geodäsie: Frankfurt am Main, Germany, 2019.

66. Ali, K.F.; De Boer, D.H. Spatially distributed erosion and sediment yield modeling in the upper Indus River basin. Water Resour. Res. 2010, 46, 1-16. [CrossRef]

67. Freeman, T.G. Calculating catchment area with divergent flow based on a regular grid. Comput. Geosci. 1991, 17, 413-422. [CrossRef]

68. O'Callaghan, J.F.; Mark, D.M. The extraction of drainage networks from digital elevation data. Comput. Vis. Graph. Image Process. 1984, 28, 323-344. [CrossRef]

69. Nobre, A.D.; Cuartas, L.A.; Hodnett, M.; Rennó, C.D.; Rodrigues, G.; Silveira, A.; Waterloo, M.; Saleska, S. Height Above the Nearest Drainage-A hydrologically relevant new terrain model. J. Hydrol. 2011, 404, 13-29. [CrossRef] 
70. Nickel, J.P.; Fuchs, S.; Hörner, L. Aktuelle Daten zur stofflichen Belastung von Mischwasserentlastungen. Korrepondonz Abwasser Abfall (KA) 2021, 68, 1-7.

71. Kiemle, L.; Wagner, A.; Hüsener, J.; Fuchs, S.; Henning, K.; Haile, C. Modellierung der Nährstoffeinträge in die Fließgewässer BadenWürttembergs für die Aktualisierung der Bewirtschaftungspläne nach WRRL: Modellbeschreibung und Ergebnisse der MONERIS-BW Version "August 2019"; unpublished; Karlsruhe, Germany, 2019.

72. Horowitz, A.J. Determining annual suspended sediment and sediment-associated trace element and nutrient fluxes. Sci. Total. Environ. 2008, 400, 315-343. [CrossRef]

73. Fischer, F.K.; Auerswald, K.; Winterrath, T.; Brandhuber, R. Klimabedingte Zunahme der Regenerosivität seit 1960. Korresp. Wasserwirtsch. 2020, 13, 609-613.

74. Brandhuber, R.; Treisch, M.; Fischer, F.; Kistler, M.; Maier, H.; Auerswald, K. Starkregen, Bodenabschwemmungen und Struzfluten: Beobachtungen und Analysen im Mai/Juni 2016; Bayerische Landesanstalt für Landwirtschaft (LfL), Freising-Weihenstephan: Munich, Germany, 2016.

75. Carter, J.; Owens, P.N.; Walling, D.E.; Leeks, G.J.L. Fingerprinting suspended sediment sources in a large urban river system. Sci. Total Environ. 2003, 314-316, 513-534. [CrossRef]

76. Auerswald, K.; Wiegand, S. Ist die Erosionsschadenskartierung geeignet, um im Sinne der Bundes-Bodenschutz- und Altlastenverordnung Erosionsflächen zu identifizieren und den Bodenabtrag festzustellen? Bodenschutz 2001, 4, 123-128.

77. Bug, J.; Mosimann, T. Rill erosion in Lower Saxony-Results of an 11-year survey on the expansion, small-scale distribution and cause of soil erosion. Die Bodenkult. 2012, 63, 63-75.

78. Mosimann, T.; Bug, J.; Sanders, S.; Beisiegel, F. Bodenerosionsdauerbeobachtung in Niedersachsen 2000-2008: Methodik, Erosionsgeschehen, Bodenabträge und Anwendung der Ergebnisse; Inst. für Physische Geographie und Landschaftsökologie Leibniz-Univ. Hannover: Hannover, Germany, 2009; ISBN 9783927053472.

79. Auerswald, K.; Fiener, P.; Dikau, R. Rates of sheet and rill erosion in Germany-A meta-analysis. Geomorphology 2009, 111, 182-193. [CrossRef]

80. Young, R.A.; Onstad, C.A.; Bosch, D.D.; Anderson, W.P. AGNPS: A nonpoint-source pollution model for evaluating agricultural watersheds. Kournal Soil Water Conserv. 1989, 44, 168-173. 